\title{
The Social Support Influence for Prospective Teacher on Their Teaching Career Perceptions
}

\author{
Heru Wahyu Herwanto, Sigit Purnomo \\ Electrical Engineering Department, Engineering Faculty \\ Universitas Negeri Malang \\ Malang, Indonesia \\ heru_wh@um.ac.id
}

\begin{abstract}
The purpose of this study is to explore how much influence of social support on teacher career perception of prospective teachers. This research uses descriptive correlational method with quantitative approach. The population of this research was 129 students of the $5^{\text {th }}$ semester of Informatics Engineering Education Study Program. Data were collected using a questionnaire for social support and career perception variables. Data were then analyzed using correlational statistic approach. The result of the research was teacher's career perception on very high category $(82.63 \%)$, while social support in high category $(64.53 \%)$. Then there is a significant relationship between social support and career perception. The amount of influence on the perception of social support and teacher career was $13.00 \%$ (effective contribution).
\end{abstract}

Keywords — teaching career perception, social support

\section{INTRODUCTION}

Professionalism is an idea that causes certain work activities in society with high skill and spirit of devotion, yet ready to give helps to others in needs [1]. On the other hand, Longman [2] says that professionalism is the behavior, expertise or qualities of a professional person. A person who has professionalism sense always encourages himself to realize professional work.

Education is one way to prepare professionals in a particular field. Teacher education is an institution that aims to prepare students to become professional teacher candidates. The success of prospective teachers in learning depends on many factors. One of them is the seriousness of the students in preparing a candidate of professional teacher.

Students' sincerity toward their study is influenced by their perception of the work in accordance with the field of study taken. Positive perceptions will make them spiritful and earnest to study. It will make them get satisfaction and become a candidate for high quality workers. Conversely, negative perceptions might make them less serious to study. If they will be graduated, they will become poor qualified graduates (prospective workers).

Human Development Index (HDI) released by UNDP [3] shows that the human development index in Indonesia is in the middle rank (rank 113 of 188 countries.)

Perception is a personal integrated activity so that whatever is in someone will participate actively in the perception. In practice, perception is influenced by several things including feelings, ability to think, and experience. Davidof \& Roger [4] say that perception is personal then perceiving something (stimulus) between one person and another will be different.
In terms of teacher careers, a negative perception will result poor prospective teachers. This will endanger national education because the key to the success of national education is in teachers.

The world of education must be able to play an active role in preparing educated human resources who are capable to face the challenges of life either locally, regionally, nationally or internationally. It is not enough to master the theories but also is willing and is able to apply them in social life, and is able to solve various problems faced in everyday life. The world of education should also be able to form prospective educators who have a positive perception of career training. Positive perception will have an impact on the interest of becoming a teacher. A high interest will make prospective teachers become professional and competent educators in their field.

In his social life, a student (prospective teacher) will not be separated from the influence of the surrounding environment. Students will always receive excitement from their environment. Walgito [4] says that the stimulus comes from within himself and from outside himself (the environment)

The establishment of a positive perception of teacher career for students depends on many things. Providing appropriate information about career training and the facilities gained are also important factors in shaping perceptions. Information about career training and teacher career development tools are gained through interaction with the environment such as family, friends, educational institutions, and the community. Families have an important role to drive, direct, and provide information in shaping positive perceptions of teacher careers. Weisnberg and Aghakhani; Creed, Falon, Hood [5] showed that the ability to focus careers is highly dependent on the social environment. While Han and Rojewski [5] say that families, friends, and teachers facilitate career preparation and transition from school to work world.

According to Papalia, Olds, Fieldman [5] social support is the support of material, information, and psychological sources derived from social relationships to help calm under stressful conditions. Individuals who obtain social support are more calm, cared for, have confidence, and are competent (Kumala and Ahyani; Ushfuriyah) [5].

\section{A. Teaching Career Perception}

Walgito [4] says perception is organization yet interpretation of the captured stimulus into something meaningful, also an integrated response. While Rachmat [7] said that perception is the experience of objects, events or 
relationships obtained by concluding information and interpret the message in the form of behavior.

Teaching career perception for students is the organization and interpretation of the stimulus received by the teacher's sense of career interpreted in the form of students' behavior, perspective and attitudes to the teaching profession. The various stimuli received about the profession of teachers by students vary, so that the perception is produced differently.

Toha [7] states the process of perception through three stages namely stimulus, registration, and interpretation. Stimuli is sensed and then sent to the brain for further process. The brain will then interpret it. This interpretation depends on the characteristics of each student, of which result in different perceptions.

There are several factors that affect a person's perception. Walgito [4] suggests there are three factors that affect the perception coverings a) the object that generates the stimulus, b) the sense apparatus, the nerves, and the central nervous system are tools for receiving the stimulus and channeling it to the brain, and c) attention, to realize or in holding perceptions required the attention, that is the main step as a preparation in order to hold a perception.

Teaching career perception is built on several aspects, namely teacher performance teacher welfare, and teacher career development [8]. The performance of teachers is related to various teachers' abilities in implementing a learning process. The performance is shown in several criteria including quality of work, accuracy, initiation, ability, and komunikas [9].

The existence of teacher performance demands must be matched by the sense of being good teachers. The welfare of teachers is regulated in the Law of the Republic of Indonesia Number 14 Year 2005 on Teachers and Lecturers. Article 14 paragraph 1 stated that in running the professionality, teachers are entitled to earn income, get promotion, obtain protection, have an opportunity to improve competence, obtain and utilize learning facilities and infrastructure, have the freedom to provide judgment and shall determine the graduation, award, and / or sanction to the learners, obtain a sense of security and safety in carrying out the task, have the freedom to associate within professional organizations, have the opportunity to play a role in the determination of education policy, have opportunities to develop and enhance academic and competency qualifications, and obtain training and professional development in the field.

In addition, teacher is also entitled to (a) the professional allowance, as mentioned in article 16, paragraph 1; (b) functional allowances, as mentioned in article 17, paragraph 1; (c) special allowances, as set forth in article 18, paragraph 1; (d) also provided with educational allowance, educational insurance, scholarships, awards; and (e) the convenience of his son and daughter for education, and health care.

\section{B. Social Support}

In life, humans will not be separated from the influence and support of the environment. Support can be obtained from the family environment, peers and the surrounding community.
Social support consists of verbal and nonverbal information or suggestions, tangible assistance, or action offered by social friend or inferred by their presence and has emotional or behavioral benefits for the recipient [10].

While Uchino in Sarafino and Smith [11] stated "social support refers to comfort, caring, self-esteem, or help available to someone from another person or group".

Social support has also been defined as an information from others who are loved and cared for, viewed and respected, and part of the communication network and shared obligations (Cobb, Cohen \& Wills, Seeman in Kim, Sherman and Taylor)[12].

Social support effectively reduces psychological stress, such as depression or anxiety during times of stress (Fleming e in Kim, Sherman and Taylor) [12]. Barera in Siedlecki [13] also provides an initial definition of social support that it refers to various forms of assistance and help provided by family members, friends, neighbors, and others.

The basic form of social support functions five things [14], namely: (1) material support, (2) emotional support, (3) award support, (4) information support, and (5) social integrity support. Material support is a real support while emotional support is associated with the guarding of emotional states, affections, and expressions. Award support is a support in the form of a positive assessment. Information support in the form of providing necessary information. While the support of social integrity is the feeling of the individual as part of a group.

Sarafino and Smith formulate forms of social support based on Cutrona and Gardner and Uchino [11]. They delivered social support consisting four forms namely emotional or esteem support, tangible or instrumental support, informational support, and companionship support.

Emotional or esteem support (emotional support or reward) is a form of support expressed through empathy and care. This support shows a positive appreciation of the individual, the support / approval of the individual's ideas or feelings and the positive or negative comparisons of the individual with others who are better or worse.

Tangible or instrumental support (real or instrumental support) is a direct support in a form of material or service assistance that is useful for solving practical problems. This assistance usually includes material, financial, service, time and energy assistance or things that are obviously needed by the individual.

Informational support is a form of support in the form of giving advice, suggestions, instructions, directions, inputs, rewards, guidance or giving feedback and information the individual needs on what to do to solve the problems at hand.

Companionship support is a support that refers to the willingness of others to spend time with the individual, creating an atmosphere of mutual belonging, so that the individual feels accepted in a group.

Social support will be more meaningful if given by people close to him. Taylor in Sepfitri [15] said that social support would be more useful for the individual if given by parents, 
family, friends, and people who have closeness to other relationships. While Winemiller, Noller, Feeney, Peterson in Sepfitri [15] stated there are several sources of social support: family, friends, spouses, organizations or groups, coworkers, and neighbors. The effectiveness of social support will be effective if the support is perceived to be strong by the receiving individual [11].

Acceptance of social assistance has six factors: (1) the origin of the support giver; (2) usefulness; (3) characteristics of personality support, habits, and social roles; (4) conformity with the problems at hand; (5) the timing of support; and (6) duration of support [14]. Sarafino and Smith [11] stated the cause of the rejection of support was: First, the aid did not meet the needs. Second, the type of support is less important. From both the above problems, it can be concluded that social support will have a positive effect if the person with social support is aware of the specific needs in accordance with the problem.

\section{METHOD}

This research is an expost-facto causal comparative research which aims to examine the events that have happened previously to know the cause of the happening phenomena [16]. The type of research design is descriptive correlational with quantitative approach. This aims of research is to reveal how much social support on teacher career perceptions. The dependent variable (Y) of this study is career teacher perception, while the independent variable $(\mathrm{X})$ is social support.

\section{A. Population and Sample}

Population in this research includes students of PTI study program which had enough education in college. In this case the population was students in the fifth semester. The population was 195 students.

The sample of this study was taken using methods developed by Isaac \& Michael. Using a 5\% error rate, 95\% confidence interval and population 195 then a minimum sample size of 129 students were obtained. The sampling technique used simple random sampling.

\section{B. Research Instruments}

The instruments used in this study were questionnaires. This instrument was used to collect social support data and career teacher perceptions. There were 4 scales (likert's scale) with answers ranging from strongly agree, agree, disagree and strongly disagree.

Social support wi meticulously consisted of 4 aspects that include emmotional or Esteem Support (ES), Tangible or Instrumental Support (TIS), Informational Support (IS) and Companionship Support (CS). Aspects of ES include attention, caring, empathy, positive appreciation, and approval of ideas and the ideas themselves [11]. Aspects of TIS consist of direct assistance in the form of material and direct assistance in the form of action [11]. Aspects of IS consist of getting advice or advice, getting instructions or directions, getting explanations of information, and getting feedback on behavior or opinions
[11]. While Aspect CS consists of the presence of the people closest and sense of togetherness.

Career perception is measured using three aspects of perception: teacher performance, teacher welfare, and career development [8]. Perceptions of teacher performance include a) performance quality, b) work accuracy, c) work initiatives, d) capabilities, and e) communication. Aspects of teacher welfare perception consist of a) income, b) social welfare, c) task \& achievement awards, d) legal protection, and e) intellectual property rights. While the aspects of career development perception include a) coaching and professional development of teachers, and coaching and teacher career development.

The test instrument consists of validity and reliability tests. Validity test is done by using Parson Produck Moment with significance of 0.05 . While the reliability test using components $(\alpha)$. The level of reliability used using 5 levels is very low (between 0 and 0.2 ), low (from 0.2 to below 0.4 ), moderate (from 0.4 to below 0.6 ), high (from 0.6 to below 0.8 ) and very high (from 0.8 to 1 ) [17].

\section{Data analysis}

Data analysis performed included data descriptive analysis, prerequisite analysis, hypothesis analysis and predictor donation analysis.

\section{1) Descriptive Analysis}

Descriptive analysis is intended to describe the data to be used without generalizing the data. This analysis is done by calculating mean (Mean), standard deviation (SD), median $(\mathrm{Me})$, mode (Mo), maximum value and minimum value. Quality questionnaires are categorized by the following formula [18].

$$
\text { Quality }=\frac{\sum \text { Score }}{\sum \text { Max Score }} \times 100 \%
$$

The quality of the questionnaires is divided into 4 levels: a) very low $(0-20 \%)$, low $(20-40 \%)$, moderate $(40-60 \%)$, high (60-80), and very high (80-100\%).

\section{2) Prerequisite Analysis}

Testing of prerequisite analysis performed is normality, linearity, autocorrelation, and heterokedatisitas tests.

Normality test is done to know the distribution of data. This test uses smirnov kolmogorof test. If $p$ value is more than 0.05 , then the data are normally distributed. Conversely, if the $\mathrm{p}$ value is less than 0.05 , then the data distribution is not normal.

Linearity test is to determine whether the variables studied have a linear relationship. To know the data is linear or not, it is necessary to look at the level of significance on linearity line. If $\mathrm{p} \mathrm{Sig.} \leq 0.05$ then the data is not linear and if $\mathrm{p} \mathrm{Sig.} \geq 0.05$, meaning the data is linear patterned.

Autocorrelation test to determine whether there is correlation between user errors in period $t$ with error in the previous $t$ period $(t-1)$ on the linear regression model used. Detection autocorrelation using Run test with rules if the value Asymp Sig (2-tailed)> 0.05 then there is no autocorrelation. 
Conversely, if the value of Asymp Sig (2-tailed) $<0.05$ then autocorrelation occurs.

Heteroskedasticity test aims to determine whether the data in this study has a different variance. Detection of heteroscedasticity by looking at the scatter plot chart between the predicted dependent variable, ie ZPRED (X axis) with SDRESID ( $Y$ axis). If the data point in the plot is scattered and does not form a pattern then it can be said there is no heterokedastisitas.

\section{3) Hypothesis Analysis}

Hypothesis testing to find out the relationship between social supports with teacher career perception. The technique used is correlation analysis technique. The decision is taken by looking at the probability value in the Sig column. If the value is less than $0.05(\mathrm{p} \leq 0.05)$, then the hypothesis is accepted so that there is a positive and significant relationship between the two variables, if $p$ is greater than or equal to 0.05 , there is no positive and significant relationship .

\section{4) Predictor Donation Analysis}

The support of variable $\mathrm{x}$ to variable $\mathrm{y}$ is determined by how big the contribution of predictor $\mathrm{x}$ to $\mathrm{y}$. The contribution of predictors is calculated by look at the $\mathrm{R}$ Square value of linear regression analysis. $\mathrm{R}$ square (coefficient of determination) ranges from 0 to 1 . The smaller number $R$ square, indicate the weaker relationship between variables $\mathrm{X}$ and Y (Priyatno, 2012: 83).

\section{RESUlT AND DiscUSSION}

The result of social support instrument test obtained 41 items of valid instrument with reliability of 0.909 . While the validity test results of the instrument of perception of career perception was 49 valid items. Both tests were in very high category.

Results of data collection of social support obtained score 13652. The maximum number of scores that could be achieved is 21156. Thus the social support students according to 129 respondents was $64.53 \%$ which belonged to the high category. While the mean value was 105.83 , the median value was 106 , the standard deviation value was 9.3, the minimum value was 83 , and the maximum value was 129 .

Results of career perception data retrieval from 129 students got a score of 20893. The maximum number of scores that could be achieved 25284. So the career perception of 129 respondents was $82.63 \%$ with very high category. While the mean value was 161.9 , the median value was 160 , the standard deviation value was 13.37 , the minimum value was 125 , and the maximum value was 192 .

With kolmogorov smirnov, normality test got significance for social support equal to 0.200 and perception of career equal to 0.185 . From both values it could be concluded that the data were normally distributed (significance $>0.05$ ).

Test linearity between variables social supports $(\mathrm{X})$ with career perception $(Y)$ was significant $(p=0.000)$. This value is less than 0.05 so it could be concluded that the relationship between the two variables was linear.
The results of autocorrelation test using Run test obtained by Asymp.sig (2-tailed) value of 0.71 . This value was greater than 0.05 then it could be concluded there was no autocorrelation.

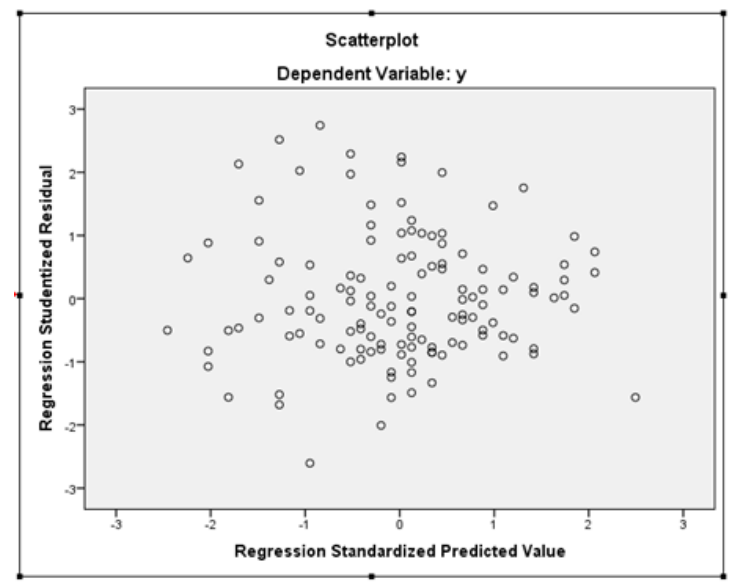

Fig. 1. Heterokedastisitas Test

The result of the heterocedasticity test was a random dot pattern/scatchered. Thus it could be concluded that there was no heterokedastisitas.

Hypothesis test was done by looking at the correlation between the two variables. The correlation was done between the dependent variable $\mathrm{Y}$ (career perception) and the independent variable $\mathrm{X}$ (social support) by using Pearson Corelation. Hypothesis test resulted value of 0.361 with sig (2tailed) equal to 0.00 . With the value of sig (2-tailed) less than 0.05 it could be concluded there was a significant correlation between social support and student career perception.

Effective contribution of social support variable to career teacher perception was obtained from R Square value on linear regression analysis. From calculation result obtained R Square value equal to 0.13 or $13 \%$. Thus it could be said that the magnitude of the influence of social support variables on career perception was $13 \%$. While the rest $(87 \%)$ was influenced by other variables outside of social support.

Based on the above analysis, in terms of teacher career perception, prospective teachers have a positive perception. This is evidenced by career perception score of $82.63 \%$ (very high). While social support of prospective teachers in high category $(64.53 \%)$. This means that many prospective students receive social support from the surrounding environment (family, friends, and other nearby people). Social support affects the health of the individual by providing protection against the negative effects of high stress [19][20]. When students are stressed, the support of important figures will be a useful stimulus to deal with stress. The existence of this support would make students feel comfortable and more confident in his studies, so as to obtain a good achievement. Confidence is important in the career planning and determining process. This also will affect the formation of positive perceptions of career. 
The Creed, Fallon, and Hood [5] concluded that social support from nearby people influences the exploration of youth careers. Hirschi's research [5] states that giving social support becomes an independent one in the formation of perceptions for individual career development. Tian and Fan's research [5] concluded that social support primarily from the family is an important factor that is useful for improving students' career adaptability.

However, the existence of social support is not the only aspect that affects the career perception of teacher teacher candidates. This is evidenced by the amount of social support support to career perception by $13 \%$. This means there is still another aspect $(87 \%)$ that affects the career perception of prospective teachers who have not been studied.

\section{CONCLUSION}

Based on the findings of research and discussion, the results of the study can be summarized as follows. Teacher career perception level of students is very high, the level of social support from students is high, and there is a positive and significant relationship between social supports with teacher career perceptions of students. The effective contribution of social support variables is $13.0 \%$ which means that there are other variables that also influence career teacher perception.

\section{REFERENCES}

[1] Wignjosoebroto 1999. World Education Professionalism. www. iq.eq web. id.

[2] Bodrova, E., Germeroth, C. \& Leong, D.J. 2013. Play and Selfregulation. American Journal of Play, (Online), 6 (1): 111-123, (http://www.du.edu/marsicoinstitute/pressroom/6-1-article-play-andself-regulation.pdf), accessed January 19, 2017.

[3] UNDP.2017. Human Developmen Report. (online) http://hdr.undp.org/en/countries/profiles/IDN

[4] Walgito, Ben. 2004. Introduction to General Psychology. Yogyakarta: Andi.

[5] Hastoprojokusumo, M.B. 2016. Influence of Perceived Social support on End-Year Career Adaptability. Unpublished thesis. Yogyakarta: Faculty of Psychology of Sanata Dharma University.

[6] Rakhmat, Jalaluddin. 2007. Communication Psychology (revised edition). Bandung: PT. Youth Rosdakarya.

[7] Toha, Miftah. 2003. Leadership in Management. Jakarta: Raja Grafindo Persada.

[8] Suprihatiningrum, Jamil. 2013. Professional Teachers: Teacher Performance, Qualification \& Competency Guidelines. Jogjakarta: ArRuzz Media

[9] Sedarmayanti. 2011. Human Resource Management, Bureaucracy Reform and Civil Servant Management. Bandung: PT Refika Aditama.

[10] Gottlieb, B.H. 1983. Social Support Strategies (Richard H. Price, Ed.). California: Sage Publication, Inc.

[11] Sarafino, E.P. and Smith, T.W. 2011. Health Psychology: Biopsychosocial Interactions. United States of America: John Wiley \& Sons, Inc.

[12] Kim, H.S., Sherman, D.K. \& Taylor, S.E. 2008. Culture and Social Support. American Psychological Association, (Online), 63 (6): 518526, (http://people.psych.ucsb.edu/sherman/david/kimshermantaylor. ap.2008.pdf), accessed January 19, 2017.

[13] Siedlecki, K.L., Salthouse, T.A., Oishi, Shigehiro \& Jeswani, Sheena. 2013. Social Indicators Research (Alex C. Michalos, Ed.). Springer: Soc Indic Res.

[14] Fauziyah, I.K. 2016. Relationship of Parents Social Support and Academic Self-Efficacy to Adjustment of VII Second Class Students of
SMP Plus Darussalam Blokagung Banyuwangi. Unpublished thesis Malang: Faculty of Psychology State Islamic University Maulana Malik Ibrahim Malang.

[15] Sepfitri, Neta. 2011. The Effect of Social Support on Student Achievement Motivation MAN 6 Jakarta. Unpublished thesis. Jakarta: Faculty of Psychology State Islamic University Syarief Hidayatullah.

[16] Sukardi. 2003. Research Methodology of Competency Education and Practice. Jakarta: PT Bumi Aksara

[17] Ruseffendi. 1994. Fundamentals of Education Research and Other NonExtractive Fields. Semarang: IKIP Semarang Press.

[18] Iskandar. 2009. Education and Social Research Methodology (Quantitative and Qualitative). Jakarta: Gaung Persada Press.

[19] Cohen, Sheldon \& Wills, Thomas. (1985). Stress, Social Support, and the Buffering Hypothesis. Psychological bulletin. 98. 310-57. 10.1037 / 0033-2909.98.2.310.

[20] Fibrianti, I.D. 2009. Relationships Anatara Social Support Parents with Academic Prokrastinasi in Completing Thesis on Student Faculty of Psychology Diponegoro University of Semarang. Unpublished thesis. Semarang: Faculty of Psychology Dipenegoro University of Semarang. 